\title{
8.2 розробка системи економіко-математичного моделювання у дослідженні зони вільної торгівлі України з ЄС
}

Важливою передумовою забезпечення динамічного розвитку національної економіки є іiі інтеграція у світовий економічний простір, що відповідає як сучасним тенденціям глобалізації, так і необхідності поглиблення цивілізованих зовнішньоекономічних відносин України з іншими країнами. Перш за все, це стосується проголошеного нашою державою курсу на інтеграцію до Європейського Союзу (СС), що в перспективі має забезпечити поетапну коінтеграцію входження національної економіки до світової економічної системи, а відтак й підвищення глобальної конкурентоспроможності за умови виваженого державного регулювання.

Важливість вибору правильних орієнтирів зовнішньоекономічної політики набуває особливої уваги в умовах посилення глобалізаційних тенденцій у світі та загострення конкурентного протистояння на світових ринках. Сучасний етап соціально-економічного розвитку України наочно ілюструє, що без правильної, науково обгрунтованої, всебічно зваженої та послідовно здійснюваної зовнішньоекономічної політики не може бути успішно реалізована жодна національна стратегія економічного та соціального розвитку, яка передбачає інтеграцію нашої країни у європейський простір. Водночас зближення нашої держави 3 Євросоюзом неможливе без розробки системи економікоматематичного моделювання, виявленні ризиків, які виникають у процесі створення зони вільної торгівлі (ЗВТ), проблеми виходу українських товаровиробників на європейські ринки, що неодмінно призведе до трансформації більшості секторів національної економіки.

Зона вільної торгівлі України та ЄС передбачає співпрацю за різними напрямами, що переважно містяться у площині питань зовнішньоторговельної сфери (зокрема торгівлі товарами та послугами, митно-тарифного регулювання, інвестиційної та конкурентної політики та врегулювання суперечок).

Для визначення поточного стану, тенденцій та перспектив розвитку ЗВТ можна використовувати різноманітні економіко-математичні методи, які умовно 
можна поділити на дві категорії - неформалізовані (якісні) та формалізовані (кількісні) (дивись табл. 8.2.1).

Таблиця 8.2.1.

\section{Узагальнення системи економіко-математичного моделюванні при}

досліджені зони вільної торгівлі України з СС [343]

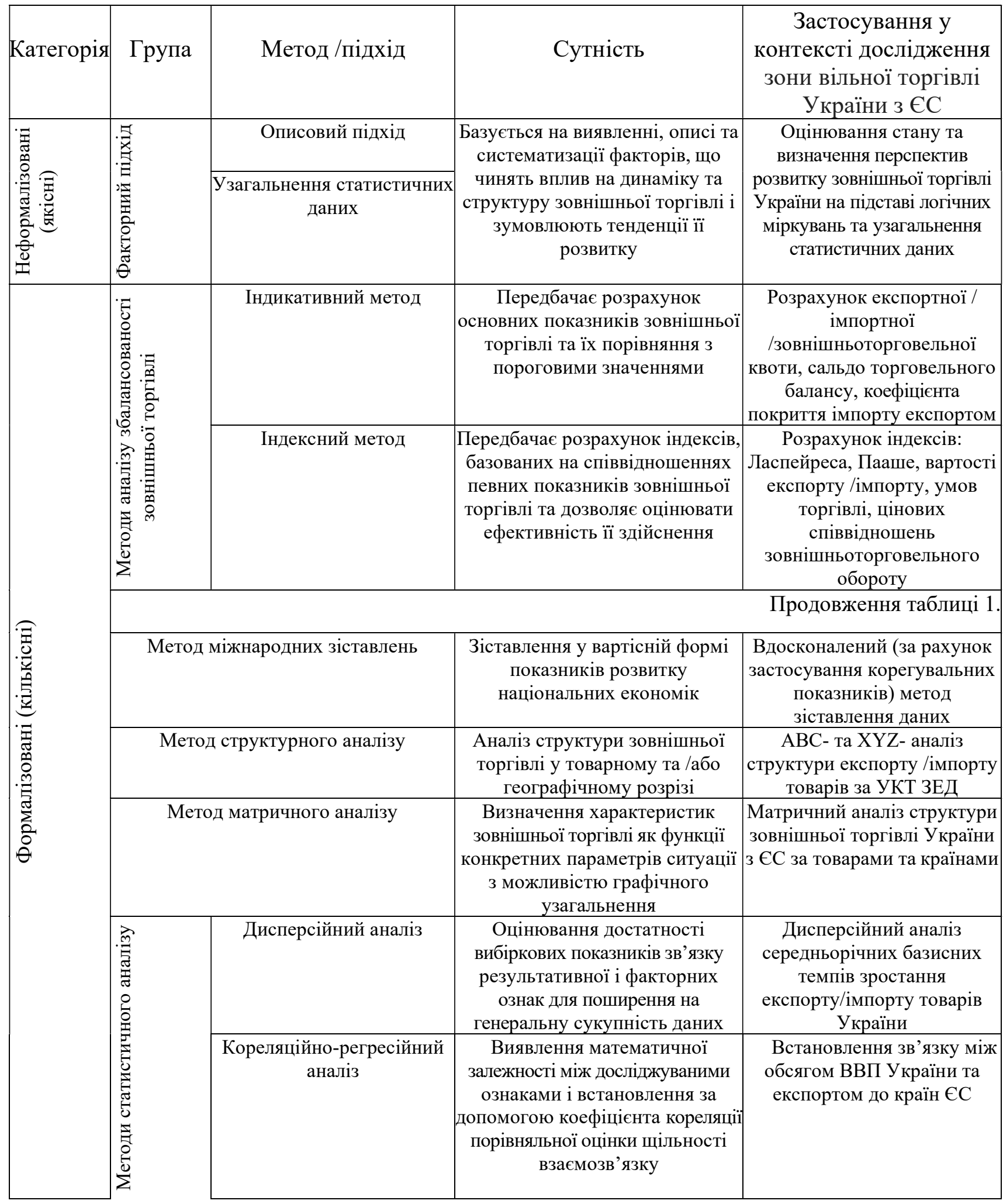




\begin{tabular}{|c|c|c|c|c|}
\hline & \multicolumn{2}{|c|}{$\begin{array}{c}\text { Сценарне планування } \\
\text { (прогнозування) }\end{array}$} & \begin{tabular}{|c|} 
Конструювання варіантів \\
розвитку економічного суб'єкта \\
на основі визначення загальних \\
факторів впливу
\end{tabular} & $\begin{array}{c}\text { Використання } \\
\text { автоматизованих моделей } \\
\text { загальної економічної } \\
\text { рівноваги та міжгалузевого } \\
\text { балансу, зокрема GTAP }\end{array}$ \\
\hline$\underline{\Xi}$ & \multicolumn{2}{|c|}{ Гравітаційне моделювання } & $\begin{array}{c}\text { Базується на ідеї гравітаційного } \\
\text { тяжіння: сила взаємодії між } \\
\text { економічними суб'єктами є } \\
\text { прямо пропорційною добутку } \\
\text { показників їх значущості та } \\
\text { зворотно пропорційною відстані } \\
\text { між ними }\end{array}$ & $\begin{array}{c}\text { Гравітаційна модель торгівлі } \\
\text { України } \\
\text { з країнами Європейського } \\
\text { Союзу }\end{array}$ \\
\hline 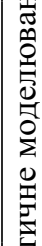 & \multicolumn{2}{|r|}{$\begin{array}{c}\text { Методологія нечіткої } \\
\text { логіки }\end{array}$} & \begin{tabular}{|c|} 
Побудова лінгвістичної моделі \\
кількісно невимірюваних \\
економічних величин 3 \\
подальшою їх трансформацією у \\
числову модель на основі \\
системи правил \\
\end{tabular} & $\begin{array}{c}\text { Модель прогнозування } \\
\text { успішності здійснення } \\
\text { експортно-імпортних } \\
\text { операцій з країнами ЄС }\end{array}$ \\
\hline 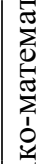 & \multicolumn{2}{|c|}{ Імітаційне моделювання } & $\begin{array}{c}\text { Відтворення в часі } \\
\text { (прогнозування) розвитку } \\
\text { зовнішньої торгівлі за переліком } \\
\text { сценаріїв }\end{array}$ & $\begin{array}{c}\text { Прогнозування розвитку } \\
\text { зовнішньої торгівлі товарами } \\
\text { України з ЄС на } \\
\text { середньостроковий період }\end{array}$ \\
\hline · & \multirow[t]{2}{*}{ 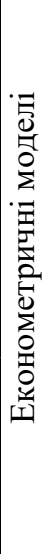 } & $\begin{array}{c}\text { Моделювання } \\
\text { одновимірних часових } \\
\text { рядів } \\
\text { (детерміністський } \\
\text { підхід) }\end{array}$ & \begin{tabular}{|c|} 
Сукупність математико- \\
статистичних методів аналізу, \\
призначених для виявлення \\
структури часових рядів та їх \\
прогнозування, є підгрунтям для \\
побудови детермінованих \\
(зазвичай, трендових) моделей \\
певного функціонального типу
\end{tabular} & $\begin{array}{c}\text { Трендові моделі } \\
\text { двосторонньої торгівлі між } \\
\text { Україною та певними } \\
\text { країнами ЄС; економетричні } \\
\text { моделі } \\
\text { зовнішньоторговельного } \\
\text { обороту України загалом та } 3 \\
\text { окремими групами країн } \\
(\mathcal{C}) \\
\end{array}$ \\
\hline & & $\begin{array}{c}\text { Стохастичне } \\
\text { моделювання } \\
\text { (ймовірнісний підхід) }\end{array}$ & $\begin{array}{c}\text { Визначення ймовірностей різних } \\
\text { станів системи } \\
\text { в майбутньому на основі відомої } \\
\text { інформації щодо ії поточного та } \\
\text { попереднього станів }\end{array}$ & $\begin{array}{c}\text { Гнучкий інструментарій } \\
\text { аналізу та прогнозування } \\
\text { зовнішньої торгівлі }\end{array}$ \\
\hline
\end{tabular}

Під неформалізованими методами варто розуміти такі, що грунтуються на логічних процедурах узагальнення проявів дійсності i не передбачають підтвердження авторських висновків певною аналітичною залежністю та розрахунками. Формалізований метод передбачає проведення дослідження 3 використанням кількісного аналізу і дозволяє уникнути помилок суб'єктивізму, типових при неформалізованому підході. Саме використання кількісних методів дає грунтовні прогнози тенденцій та динаміки розвитку ЗВТ Україна - СС.

Факторний підхід до аналізу зовнішньої торгівлі України реалізується у роботах науковців як дослідження винятково описового характеру [344] або грунтується на певних статистичних даних [345]. Щодо доцільності використання факторного підходу при аналізі зовнішньої торгівлі за сучасних умов невизначеності важливо те, що встановлені дослідниками передумови розвитку 
зовнішньої торгівлі України здебільшого грунтовні та базуються на виявленні й узагальненні об'єктивних тенденцій.

Неформалізований аналіз фіксує поточний стан та окреслює загальні перспективи розвитку зовнішньої торгівлі, але не дає реальної можливості для прогнозування ii обсягів, динаміки та структури. Додатково придатність результатів неформалізованого аналізу для адекватного прогнозування зовнішньої торгівлі обмежує наявність несподіваних та неочікуваних факторів. Адже стан та тенденції розвитку зовнішньоторговельних відносин України останнім часом визначаються не стільки об'єктивними економічними закономірностями, скільки трансформацією інтеграційних пріоритетів держави через різку зміну геополітичної ситуації.

Отже, неформалізований аналіз на основі факторного підходу - вагома підстава для оцінювання поточного стану та встановлення тенденцій розвитку зовнішньоторговельних відносин держави. Доцільно його використовувати у комплексі 3 формалізованими методами дослідження, що сприятиме підвищенню обгрунтованості прогнозів динаміки та структури зовнішньої торгівлі України.

Формалізований (кількісний) аналіз передбачає проведення дослідження 3 використанням кількісних методів та розрахунків. Найбільш поширені методи аналізу збалансованості зовнішньої торгівлі. Вчені активно застосовують індексний метод, за допомогою якого описують динаміку експортно-імпортних операцій, оцінюють виконання обов'язків за контрактами; аналізують вплив на розвиток зовнішньоекономічних операцій змін цін, кількості товарів, структури постачань; визначають ефективність зовнішньоекономічних операцій.

У роботах науковців використовується індексний метод для розрахунку таких основних показників зовнішньої торгівлі: експортної, імпортної та зовнішньоторговельної квоти, сальдо торговельного балансу, коефіцієнта покриття імпорту експортом. Метод аналізу збалансованості зовнішньої торгівлі, який передбачає розрахунок зазначених показників (індикаторів) та їх 
порівняння $з$ пороговими значеннями, пропонується визначати як індикативний метод.

Використання індексного та індикативного методів аналізу (дивись табл. 8.2.2) дозволяє систематизувати та формалізувати інформацію щодо поточного стану зовнішньої торгівлі, визначати ключові тенденції [346], чинники впливу та ресурси зростання обсягів зовнішньоекономічної діяльності [347]. Водночас, розрахунок індикаторів та індексів зовнішньої торгівлі дає лише статичну картину, не дозволяє формалізувати зв'язки між змінними ситуації та давати грунтовні прогнози динаміки відповідних показників.

Таблиця 8.2.2.

Показники, що застосовуються при індексному та індикативному методі аналізу зовнішньої торгівлі України [346,347]

\begin{tabular}{|c|c|c|}
\hline Показник & Формула розрахунку & Економічна інтерпретація \\
\hline $\begin{array}{c}\text { Експортна } \\
\text { квота }\end{array}$ & $\kappa_{\mathrm{e}}=\frac{\text { Експорт }}{\text { ВВП }} \times 100 \%$ & $\begin{array}{l}\text { Характеризує ступінь відкритості економіки країни. } \\
\text { За критерієм Світового банку економіка країни } \\
\text { вважається відкритою, якщо на макрорівні експортна } \\
\text { квота перевищує 35\%, якщо ж ії значення значно } \\
\text { вище, то економіка вважається “надвідкритою”, що } \\
\text { свідчить про залежність від кон'юнктури світових } \\
\text { ринків і вразливість до зовнішніх шоків. }\end{array}$ \\
\hline \multicolumn{3}{|r|}{ Продовження таблиці 2.} \\
\hline Імпортна квота & $\mathrm{K}_{\mathrm{i}}=\frac{\text { Імпорт }}{\mathrm{BB \Pi}} \times 100 \%$ & $\begin{array}{l}\text { Характеризує ступінь імпортної залежності країни. } \\
\text { Безпечним для економіки країни вважається значення } \\
\text { Кі } \leq 15 \% \text {, перевищення свідчить про велику } \\
\text { залежність економіки країни від зовнішніх поставок, } \\
\text { що обумовлюється слабкістю національного } \\
\text { виробництва. }\end{array}$ \\
\hline $\begin{array}{l}\text { Зовнішньотор- } \\
\text { говельна квота }\end{array}$ & ЗТк $=\frac{\text { Експорт }+ \text { Імпорт }}{\text { ВВП }}$ & $\begin{array}{l}\text { Економіка вважається відкритою, } \\
\text { зовнішньоторговельний оборот у відношенні до ВВП } \\
\text { більше за одиницю. }\end{array}$ \\
\hline $\begin{array}{c}\text { Коефіцієнт } \\
\text { покриття } \\
\text { імпорту } \\
\text { експортом }\end{array}$ & $\mathrm{K}_{\text {п }}=\frac{\text { Експорт }}{\text { Імпорт }}$ & $\begin{array}{l}\text { Характеризує співвідношення експорту } 3 \text { імпортом, } \\
\text { що показує ступінь збалансованості зовнішньої } \\
\text { торгівлі. } \\
\text { При активному сальдо торговельного балансу Кп>1, } \\
\text { при пасивному - Кп<1. Різниця (1-Кп) характеризує } \\
\text { масштаб його дефіциту (-) чи профіциту }(+) \text {. }\end{array}$ \\
\hline $\begin{array}{c}\text { Індекс } \\
\text { Ласпейрса }\end{array}$ & $\begin{array}{l}\mathrm{I}_{\mathrm{p}}^{L}=\frac{\sum \mathrm{p}_{1} q_{0}}{\sum p_{0} q_{0}} \text {, де } p_{1} \text { та } p_{0} \\
\text { - ціна товару відповідно в } \\
\text { поточному та базовому } \\
\text { періодах, } q_{1}-\text { кількість } \\
\text { товару в базисному періоді. }\end{array}$ & $\begin{array}{l}\text { Індекс цін за формулою Ласпейреса визначається як } \\
\text { середня гармонічна зважена } 3 \text { відносних цін, де } \\
\text { як ваги використовується вартість окремих товарів за } \\
\text { попередній період. На цей індекс не впливають будь- } \\
\text { які кількісні зміни, бо він характеризує лише цінові } \\
\text { співвідношення по товарах, що реалізовані у } \\
\text { поточному періоді, порівняно } 3 \text { попереднім у } \\
\text { незмінному обсязі базисного періоду. }\end{array}$ \\
\hline
\end{tabular}




\begin{tabular}{|c|c|c|}
\hline Індекс Пааше & $\begin{array}{l}\mathrm{I}_{\mathrm{p}}^{\mathrm{p}}=\frac{\sum \mathrm{p}_{1} q_{1}}{\sum p_{0} q_{1}} \text {, де } p_{1} \text { та } p_{0} \\
\text { - ціна товару відповідно в } \\
\text { поточному та базовому } \\
\text { періодах, } q_{1}-\text { кількість } \\
\text { товару в поточному періоді. }\end{array}$ & $\begin{array}{l}\text { Індекс цін, розрахований за формулою Пааше, } \\
\text { грунтується на поточних вагах і дозволяє порівняти } \\
\text { тільки поточний період з базисним, що не показує } \\
\text { точної зміни ціни від одного періоду до другого, тому } \\
\text { що відображає не тільки зміну ціни, але і зміну } \\
\text { структури ваг. }\end{array}$ \\
\hline $\begin{array}{c}\text { Індекс умов } \\
\text { торгівлі }\end{array}$ & 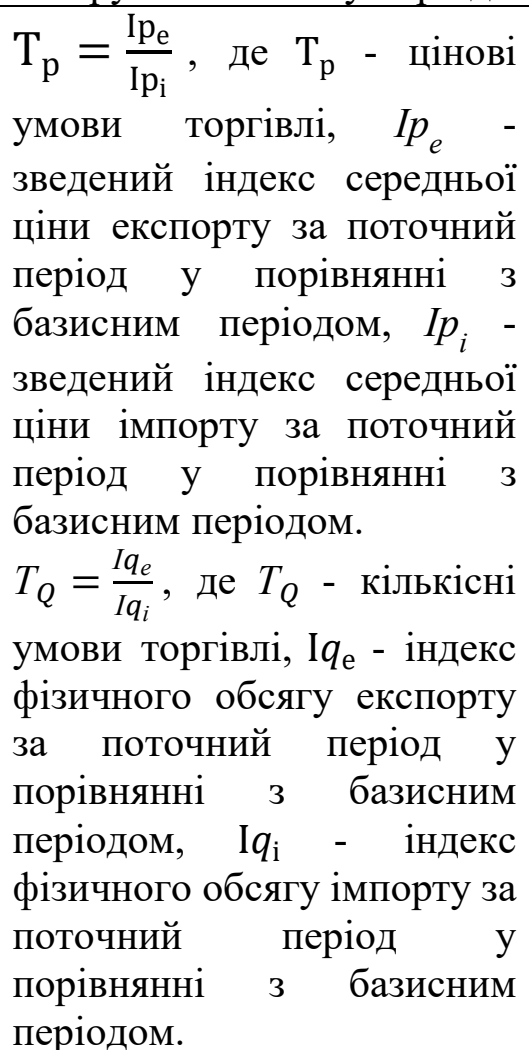 & $\begin{array}{l}\text { Індекси умов торгівлі “цінові” та “кількісні” } \\
\text { характеризують в якій мірі країна виграє (втрачає) за } \\
\text { рахунок зміни цін (кількості) товарів у зовнішній } \\
\text { торгівлі з певною країною (країнами) за відповідний } \\
\text { період часу. } \\
\text { Показник умов торгівлі вимірює відносну динаміку } \\
\text { експортних цін за певний період і розраховується для } \\
\text { проведення аналізу зовнішньоторговельної } \\
\text { діяльності, що вимірюється співвідношенням } \\
\text { середньої виручки від експорту товарів і середніх } \\
\text { витрат на імпорт за певний період часу. }\end{array}$ \\
\hline
\end{tabular}

Встановити тенденції розвитку та проаналізувати структуру зовнішньої торгівлі дозволяє метод міжнародних зіставлень [348], який передбачає аналіз комплементарності двосторонніх відносин між країнами, а саме 3 аналіз іiі мезорівня i мікрорівня. Мезорівень являє собою зовнішньоторговельну комплементарність, тобто комплементарними є товари різних галузей народного господарства, які включені у зовнішньоторговельний оборот країн-партнерів. Мікрорівень характеризує комплементарність на рівні окремих підприємств, фірм, компаній. Високий рівень комплементарності торгівлі свідчить про ефективність здійснення операцій купівлі-продажу товарів партнерами. Основним методом визначення взаємодоповняльності економік на мезорівні $\epsilon$ обчислення індексу комплементарності.

$$
\text { TCI } I_{j}=100-\sum \frac{m_{i k}-x_{i j}}{2}, \text { де }
$$

$T C I_{j}$ - індекс комплементарності торгівлі; $x_{i j}$ - частка експорту і-го товару країни 
j; $m_{i k}$ - частка товару і в загальному імпорті країни к.

Зростання показника свідчить про вище співвідношення експорту в одній країні до імпорту іншої. Якщо країну характеризує високий індекс комплементарності для експорту, це означає, що вона бере участь у розподілі продукції як експортер компонентів. Якщо ж індекс комплементарності торгівлі для імпорту більший, це означає, що ця країна $є$ учасником розподілу виробничих процесів як імпортер компонентів.

У моделі, запропонованій Д. Інь та Д. Лі індекс комплементарності вимірюється з урахуванням товарної специфікації країни [349].

$$
T C I_{i j}^{k}=\frac{x_{i}^{k} / x_{i}}{M_{w}^{k} / M_{w}} \times \frac{M_{j}^{k} / M_{j}}{M_{w}^{k} / M_{w}}, \text { де }
$$

$x_{i}^{k}$ - експорт країни i товару $\mathrm{k} ; x_{i}$ - загальний експорт країни $\mathrm{i} ; M_{j}^{k}-$ імпорт країни ј товарів $\mathrm{k} ; M_{j}$ - загальний імпорт країни $\mathrm{j} ; M_{w}^{k}-$ світовий імпорт товару $\mathrm{k} ; M_{w}$ - загальний світовий імпорт.

Цей показник визначає рівень комплементарності між пропозицією експорту і попитом на імпорт у двох країнах. Якщо індекс дорівнює нулю, країна не експортує жодних товарів або торговий партнер не імпортує жодних товарів, i 100 - коли частки експорту й імпорту збігаються [350]. Індекс TCI може бути розбитий на два індекси RCA (Індекс порівняльних переваг) i RCD (Індекс спеціалізації імпорту). Індекс RCA розраховують підставивши відповідні значення у наступну формулу:

$$
R C A_{i}^{k}=\frac{x_{i}^{k} / x_{i}}{M_{w}^{k} / M_{w}}, \text { де }
$$

де $x_{i}^{k}$ - експорт з країни і товару к; $x_{i}$ - загальний експорт з країни $\mathrm{i} ; M_{w}^{k}-$ світовий імпорт товару к; $M_{w}$ - загальний світовий імпорт.

Індекс RCA дорівнює співвідношенню між часткою продукту в загальному експорті країни і часткою того самого продукту у світовій торгівлі. Цей індекс 
розраховується, щоб визначити, чи має країна конкурентні переваги щодо певного товару. Якщо RCA $>1$, робиться висновок про те, що країна є більш експортно-орієнтованою за даним товаром і має щодо нього конкурентні переваги [350].

Аналогічно індекс RCD (Індекс спеціалізації імпорту) дорівнює співвідношенню частки певного товару в загальному обсязі імпорту країни i відповідної його частки у світовій торгівлі.

$$
R C D=\frac{M_{j}^{k} / M_{j}}{M_{w}^{k} / M_{w}}
$$

де $M_{j}^{k}-$ імпорт країни ј товарів к;

$M_{j}$ - загальний імпорт з країни j;

$M_{w}^{k}$ - світовий імпорт товару к;

$M_{w}$ - загальний світовий імпорт.

Якщо індекс RCD > 2 - висока спеціалізація імпорту; $\mathrm{RCD}<0,75$ спеціалізація імпорту відсутня; $0,75<\mathrm{RCD}<2-$ непевна сфера або відсутня яскраво виражена перевага чи несприятлива позиція.

За допомогою цих індексів можна визначити рівень комплементарності економічних зв'язків між Україною та ЄС.

Для аналізу зовнішньої торгівлі можна також застосовувати структурний аналіз, який передбачає виокремлення складових елементів (підсистем) у структурі об'єкта дослідження і визначення відносин і зв'язків між ними з метою формування комплексного уявлення про об’єкт дослідження в цілому. Різновидом структурного аналізу є АВС-аналіз, який передбачає аналізування структури зовнішньої торгівлі у товарному та/або географічному розрізі з метою визначення значущості певних груп товарів та/або регіонів у забезпеченні загального результату зовнішньоекономічної діяльності. Метод АВС - аналізу здійснюється на основі принципу Парето, тобто у зовнішній торгівлі «20\% товарів дають $80 \%$ результату». АВС-аналіз полягає у тому, що розраховується 
частка кожної товарної позиції в експорті чи імпорті країни, підсумовуються результати методом накопичення та здійснюється розподілення на три групи -3 високим рівнем ефективності експорту чи імпорту (частка - до 80\%), із середнім рівнем ефективності (частка - від 80 до 95\%), з низьким рівнем ефективності (частка - від 95 до 100\%) [351].

XYZ-аналіз використовують для класифікації груп продукції на основі показника стабільності товарної позиції в експорті чи імпорті. Цей показник прийнято вимірювати коефіцієнтом варіації, який показує, яку частину середнє квадратичне відхилення становить від середньої арифметичної величини (у відсотках), тобто наскільки великим є відхилення щодо середнього значення ознаки. У категорію Х попадають товари з коефіцієнтом варіації до 10\% (слабке коливання в часі), в категорію Y - 10-25\% (помірне коливання в часі), в категорію Z - більше 25\% (високе коливання) [351].

Коефіцієнт варіації (V) визначається за формулами [351]:

$$
\begin{aligned}
& V=\frac{\sigma}{\bar{x}} \times 100 \% \\
& \sigma=\sqrt{\frac{\sum_{\mathrm{i}=1}^{\mathrm{n}}\left(\mathrm{x}-\mathrm{x}_{\mathrm{i}}\right)^{2}}{\mathrm{n}}} \quad \text { та } \\
& \bar{x}=\frac{\sum_{i=1}^{n} x_{i}}{n} \quad \text { де, }
\end{aligned}
$$

де $\mathrm{n}$ - кількість товарних позицій, які аналізуються.

Групи AX i BX характеризуються високим рівнем стабільності, ефективності і частки реалізації продукції. Групи АY і ВY за досить високого рівня ефективності реалізації продукції характеризуються середнім рівнем стабільності. Групи AZ i BZ за значної частки реалізації продукції характеризуються низькою стабільністю. Товарна продукція таких груп знаходиться у зоні ризику, що знижує ефективність планування торгівлі і може привести до негативних наслідків (невиконання договірних обов'язків, дефіцит товарів тощо). Низький рівень ефективності і частки реалізації продукції свідчить про недостатній рівень ï якості, неефективне використання ресурсів, що вимагає застосування інноваційного підходу до виробництва, удосконалення 
технології, модернізації і заміни устаткування. Тому групам CX, CY, CZ варто приділяти особливу увагу під час формування політики, спрямованої на модернізацію устаткування, впровадження нових технологій.

Різновидом формалізованого підходу до аналізу зовнішньої торгівлі України є використання матричного аналізу, що, на основі використання правил теорії матриць, дає змогу визначити значення елементів моделі як функцію конкретних параметрів ситуації. Матричний інструментарій надає можливості для аналізу статичного (фіксованого) стану об'єкта дослідження, але не дозволяє достовірно прогнозувати його розвиток.

Наступний метод дослідження зовнішньої торгівлі України - статистичний аналіз - передбачає вивчення й порівняння цифрових даних між собою та 3 іншими. Основне завдання кореляційного і регресійного методів дослідження - аналіз статистичних даних для виявлення математичної залежності між досліджуваними ознаками та встановлення за допомогою коефіцієнта кореляції порівняльної оцінки щільності взаємозв'язку [352].

При використанні даного аналізу необхідно вирішити три основні задачі [353]:

- вибір форми зв'язку;

- визначення параметрів визначення регресії;

- оцінка щільності та надійності зв'язку.

Таким чином, необхідно визначити залежність ВВП України від експорту та імпорту. Про економічну доцільність цих факторів свідчить те, що зовнішньоекономічна діяльсть безпосередньо впливає на ВВП країни.

Аналіз математичної залежності відбувається в декілька етапів:

1. Визначається форма зв'язку між показниками, де $X$ - експорт України (незалежна змінна), а Y - обсяги ВВП країни (залежна змінна) (табл. 8.2.3). 
Таблиця 8.2.3. Дані для розрахунку кореляційно-регресійного аналізу залежності ВВП України від обсягів експорту, млрд. дол.

\begin{tabular}{|c|c|c|c|c|c|}
\hline Роки & $\mathrm{X}$ & $\mathrm{Y}$ & $\mathrm{XY}$ & $X^{2}$ & $Y^{2}$ \\
\hline 2010 & & & & & \\
\hline$\ldots$. & & & & & \\
\hline 2020 & & & & & \\
\hline Всього: & & & & & \\
\hline
\end{tabular}

2. Розраховуються середні показники:

$$
\overline{\mathrm{X}}=\frac{\sum X}{n}, \bar{Y}=\frac{\sum Y}{n}, \overline{\mathrm{XY}}=\frac{\sum X Y}{n}, \overline{X^{2}}=\frac{\sum X^{2}}{n}, \overline{Y^{2}}=\frac{\sum Y^{2}}{n} .
$$

Припустимо, що існуючий зв'язок має лінійну форму, яку можна представити у вигляді рівняння регресії:

$$
Y=\grave{a}_{0}+a_{1} X, \text { де }
$$

$a_{1}$ - коефіцієнт регресії, що показує на скільки зміниться в середньому значенні результативного показника (обсяг ВВП країни) при збільшені факторного (експорт України) на одиницю;

$\grave{a_{0}}$ - виявляє усереднений вплив на результативний показник незазначених факторів.

3. Розраховуються параметри рівняння регресії залежності обсягу ВВП України від експорту:

$$
\begin{aligned}
& \sigma_{x}=\sqrt{\overline{X^{2}}-\bar{X}^{2}}, \\
& \sigma_{y}=\sqrt{\overline{Y^{2}}-\bar{Y}^{2}}
\end{aligned}
$$

4. Далі визначаються $\sigma_{x}^{2}$ й $\sigma_{y}^{2}$, а також $a_{1}=\frac{\overline{X Y}-\bar{X} \bar{Y}}{\sigma_{x}^{2}}$ та $\grave{a_{0}}=\bar{Y}-a_{1} \times \bar{X}$

У підсумку одержуємо рівняння регресії залежності обсягу ВВП України від iï експорту:

5. Для визначення щільності зв'язку в отриманому рівнянні регресії необхідно розрахувати лінійний коефіцієнт кореляції за формулою:

$$
r=\frac{\overline{\mathrm{X} Y}-\bar{X} \bar{Y}}{\sigma_{x} \sigma_{y}}
$$


Якщо розрахований вище коефіцієнт кореляції піднести у квадрат, то отримуємо інший показник тісноти зв'язку, який називається лінійним коефіцієнтом детермінації ( $\left.r^{2}\right)$, що відображає ступінь коливання результативного показника від змін фактору.

6. Далі необхідно оцінити надійність зв’язку за допомогою коефіцієнта Ст'юдента:

$$
t=\frac{|r| \times \sqrt{n-2}}{\sqrt{1-r^{2}}}
$$

7. Для визначення відносних змін результативного показника (у \%) при зміні експорту України на 1\% необхідно розрахувати коефіцієнт еластичності:

$$
K_{e l}=a_{1} \times \frac{\bar{X}}{\bar{Y}}
$$

Для більш детального аналізу впливу зовнішньоекономічної діяльності України на ії обсяг ВВП необхідно провести кореляційно-регресійний аналіз впливу імпорту України на ВВП за схемою, зазначеною вище.

Щодо дисперсійного аналізу, важливим обмеженням при його використанні стає об'єктивна відсутність можливості урахування впливу на результативну ознаку всіх факторів макросередовища внаслідок їх чисельності та складності взаємозв'язку. Наявність неврахованих факторів призводить до того, що в окремих випадках залишкова дисперсія значно завищується та не може виступати адекватним критерієм істотності їхнього впливу. Побудова моделі дисперсійного аналізу передбачає нормальний або близький до нормального розподіл досліджуваних статистичних сукупностей. Якщо ця умова не виконується, то отримані за допомогою дисперсійного аналізу оцінки виявляються перебільшеними.

Значне місце серед методів дослідження зовнішньої торгівлі посідають методи економіко-математичного моделювання. Використання математичних методів для вирішення економічних завдань підвищує рівень обгрунтованості 
висновків щодо тенденцій розвитку зовнішньої торгівлі та рекомендацій, що надаються.

Дуже широким для оцінювання поточного стану та прогнозування тенденцій розвитку зовнішньої торгівлі $\epsilon$ спектр методів економікоматематичного моделювання.

Поширеним інструментом дослідження зовнішньої торгівлі України є сценарне планування, що передбачає варіативне конструювання майбутнього на основі визначення загальних факторів впливу на розвиток об'єкта дослідження. Підгрунтям для використання цього методу зазвичай виступають автоматизовані версії моделей загальної економічної рівноваги та міжгалузевого балансу зокрема, GTAP.

Сценарне планування на основі автоматизованих макроекономічних моделей не $є$ в чистому вигляді інструментом аналізу зовнішньої торгівлі. При використанні цих моделей визначення показників ефективності експортноімпортної діяльності є не метою, а засобом комплексного оцінювання рівня економічного розвитку країни за умови реалізації певних сценаріїв. При цьому отриманим прогнозним значенням макропоказників (у тому числі - обсягів експорту/імпорту) притаманний високий ступінь ймовірності, оскільки вони базуються на врахуванні стійких та однозначних причинново-наслідкових зв’язків між елементами ситуації. Але за сутністю сценарного планування прогнозні значення показників визначаються для обмеженого переліку варіантів майбутнього, вірогідність та вичерпність яких визначається дослідником.

Розвитком ідеї кореляційного аналізу в економіко-математичному моделюванні двосторонньої торгівлі країн є гравітаційна модель.

Гравітаційна модель пов'язує глобальні тенденції виробництва та споживання 3 глобальними тенденціями торгівлі. Популярність моделі зумовлена кількома факторами:

1. Це модель загальної рівноваги глобальної торгівлі. Моделі загальної рівноваги фіксують не тільки безпосередній вплив економічних і 
політичних змін на торгівлю між двома країнами, а й те, як він впливає на інші країни.

2. Ця модель узгоджується зі старими та сучасними теоріями міжнародної торгівлі: модель порівняльних переваг Рікардо, модель монополістичної конкуренції Кругмана, модель гетерогенних фірм на глобальних ринках Меліца.

3. Найважливіше, що вона є найбільш емпірично успішною кількісною економічною моделлю через високу пояснювальну силу: високий $r^{2}$ у регресії логарифму експорту на ВВП експортера, ВВП імпортера та відстань складає близько 0,6-0,7. При аналізі панельних даних 3 повним набором фіксованих ефектів $r^{2} \epsilon$ ще вищим - близько 0,9.

При оцінюванні моделі необіхідно враховувати всі специфічні фактори для кожної країни та кожної пари країн. Різниця, яка залишається (недоторгованість) - це відхилення від глобальних тенденцій торгівлі, що не може бути пояснене виробничою спроможністю експортера, обсягом ринку витрат імпортера, специфічними факторами торгових витрат, такими як відстань, культурні відмінності, угоди про вільну торгівлю, тарифи тощо. Модель пояснює вплив інших країн на двосторонню торгівлю. Наприклад, вона відображає вплив торговельної війни між Китаєм і США на торгівлю між Україною та СС.

Формула гравітаційної моделі є наступною:

$$
X_{i j}=\frac{Y_{i} E_{j}}{Y} \times\left(\frac{\tau_{i j}}{P_{j \Omega_{i}}}\right)^{1-\sigma}, \text { де }
$$

$\mathrm{X}_{\mathrm{ij}}$ - експорт у доларах США з країни i (експортера) до країни ј (імпортера);

$Y_{i}$ - виробнича потужність країни - експортера (ВВП);

$E_{j}$ - розмір споживчого ринку країни-імпортера (витрати в грошовому вираженні);

Y - світовий ВВП;

$\sigma$ - еластичність заміщення між різними товарами, зокрема між місцевими та імпортними товарами. Вона вимірює, наскільки попит на імпортні товари 
зменшиться у відсотковому відношенні, якщо його ціна зросте на $1 \%$. У емпіричних моделях ії величина зазвичай складає близько 4-5;

$\tau_{i j}$ - це торгові витрати між експортером та імпортером, які включають транспортні витрати, витрати на перетин кордону, оплату тарифів, задоволення нетарифних вимог у країнах-імпортерах, оплату страхових послуг;

$P_{j \text { та }} \Omega_{i}$ - це «цінові індекси», які охоплюють всю релевантну інформацію про стан всіх країн світової економіки, їх географічну позицію відносно один одного, всі торгові витрати між усіма країнами, виробництво та витрати у всіх країнах. Ці дві цифри є суттєвими, оскільки вони об'єднують всю релевантну інформацію про глобальну торговельну рівновагу в двох числах. Ці дві цифри називають багатостороннім опором імпорту та експорту.

Необхідно оцінювати гравітаційну модель торгівлі шляхом застосування методу псевдо-максимальної правдоподібності.

$X_{i j}=\exp \left(\gamma_{\text {відст }}\left(\ln\right.\right.$ відст $\left.\left._{i j}\right)+\gamma_{F T A} F T A_{i j}+Z_{i j} \gamma_{Z}+X_{i}+\xi_{j}\right) \times v_{i j}$, де

FTA - це індикатор наявності угоди про вільну торгівлю;

$Z_{i j}$ - фіксує всі змінні, які пояснюють торгові витрати;

Фіксовані ефекти $X_{i}$ та $\xi_{j}$ додані, щоб врахувати багатосторонній опір імпорту та експорту.

Прогнозовані торгівельні потоки обчислюються згідно 3 наступним рівнянням:

$$
\hat{X}_{i j}=\exp \left(\hat{\gamma}_{\text {відст }}(\ln \text { відст } i j)+\hat{\gamma}_{F T A} F T A_{i j}+Z_{i j} \hat{\gamma}_{Z}+\hat{X}_{i}+\hat{\xi}_{j}\right)
$$

А індекс недо- або переторгованості $є$ наступним:

$$
T P_{i j}=X_{i j}-\hat{X}_{i j}
$$

Негативне значення індексу вказує на потенціал зростання експорту, а позитивне - на очікуване зниження експорту в довгостроковій перспективі.

Серед економіко-математичних методів аналізу зовнішньої торгівлі слід виокремити застосування апарату нечіткої логіки. Застосування теорії нечітких 
множин створює великі можливості для оцінювання кількісно невимірюваних економічних змінних, задати які у вигляді аналітичного вираження досить важко (наприклад, «успішність експортно-імпортної діяльності», «зовнішньоторговельний потенціал країни» та ін.). Побудова лінгвістичних моделей таких змінних та подальше використання апарату нечіткої логіки дозволяє перейти від лінгвістичних до числових моделей. Підгрунтям визначення приналежності нечіткій множині (лінгвістичному терму) відповідного елементу універсальної множини зазвичай $\epsilon$ експертне оцінювання. Тому забезпечення узгодженості та неупередженості експертів - одне із очевидних обмежень при використанні методології нечіткої логіки. Другим проблемним питанням $\epsilon$ оптимізація (зменшення) розмірності масиву можливих сполучень лінгвістичних оцінок вхідних змінних моделі.

Існує також досвід імітаційного моделювання зовнішньої торгівлі України. Очевидна перевага імітаційного моделювання - можливість урахування випадкових дій та інших факторів, які створюють труднощі при аналітичному дослідженні. Імітуються елементарні явища, що формують процес, зі збереженням їх логічної структури та послідовності протікання в часі. Ризики застосування імітаційного моделювання полягають у великій ймовірності помилкової імітації. По-перше, реальні економічні процеси мають ймовірнісний характер та піддаються моделюванню тільки при введенні певного роду припущень та обмежень. По-друге, обмеження імітаційного моделювання зумовлюються обмеженою кількістю сценаріїв імітації майбутнього, які вводить до розгляду дослідник.

Окремим великим класом економіко-математичних моделей для аналізу та прогнозування впливу створення зони вільної торгівлі з СС є економетричні моделі. Класичним підходом до економетричного моделювання є розгляд послідовних значень певного показника зовнішньої торгівлі за певний часовий період як одновимірного часового ряду. Аналіз часових рядів являє собою сукупність математико-статистичних методів аналізу (зокрема, методів регресійного аналізу), призначених для виявлення структури часових рядів та їх 
прогнозування. Виявлення структури часового ряду - це підгрунтя для побудови детермінованих (зазвичай, трендових) моделей певного функціонального типу (лінійна, логарифмічна, поліном певного ступеня, експоненційна). Передумовою вибору аналітичного виду функції, що найкраще описує реальний часовий ряд, $\epsilon$ аналіз ключових показників адекватності моделі (критерій Фішера, коефіцієнт детермінації, коригований коефіцієнт детермінації).

Детерміновані моделі за своєю сутністю засновані на врахуванні впливу певних чітко визначених факторів, тоді як на реальну економічну систему впливає велика кількість факторів, які не тільки неможливо ввести до складу моделі в якості іiі параметрів, але й іноді ідентифікувати та перелічити. Це, зокрема, геополітичні трансформації, внутрішньодержавні кризи та зміна влади, локальні військово-політичні та соціальні конфлікти, світові економічні кризи, форс-мажорні обставини, несподівані зміни ринкової кон'юнктури та ін. Наявність цих факторів, напрям і ступінь їх впливу на економічну систему не прогнозована та може варіюватися. Внаслідок впливу таких внутрішніх та зовнішніх факторів поведінка системи може бути передбачена лише ймовірнісно, тобто можна визначити лише можливі вектори іiі розвитку, а не конкретні параметри в певний момент часу. В рамках ймовірнісного підходу до розуміння джерел та передумов розвитку економічних систем в 70 -х роках $\mathrm{XX}$-го сторіччя виникла та активно розвивається методологія стохастичного моделювання.

Метою стохастичного моделювання є визначення ймовірностей різного стану системи в майбутньому на основі відомої інформації щодо ії поточного та попереднього стану. Стохастичне моделювання - це гнучкий інструментарій аналізу та прогнозування зовнішньої торгівлі, використання якого має грунтуватися на об’єктивному факторному аналізі поточної економічної та геополітичної ситуації.

Отже, європейську інтеграцію визнано пріоритетним напрямом державної політики України. Як результат, аналіз структури торгового обміну та прогнозування показників зовнішньої торгівлі України з Євросоюзом (ЄС) 
набувають особливого значення. Водночас виникає потреба у виявленні взаємозалежностей і тенденцій у розвитку вітчизняної торгівлі з $\mathrm{CC}$.

Зовнішньоторговельні відносини є важливою складовою економіки будьякої держави, а для України, яка реалізує експортоорієнтовану модель економіки, їх ефективність $\epsilon$ визначальною для забезпечення іiі динамічного розвитку. Проте аналіз засвідчує, що в Україні сформувалися недостатньо ефективні товарна й регіональна структури зовнішньої торгівлі та недовикористовуються існуючі можливості поліпшення умов товарообміну. Таким чином, в державі відсутні надійні методи і механізми захисту економічних інтересів у сфері зовнішньоторговельних відносин, що дає підстави говорити про недостатню наукову обгрунтованість управлінських рішень в цій сфері. Розв'язати це завдання можна на основі розробки системи економікоматематичного моделювання, застосування якої у процесі прийняття рішень дозволяє уникнути невиправданих (а в деяких випадках i неможливих) практичних експериментів, відобразити багатогранність зв'язків, що характеризують сучасну картину торгового обміну України з $\mathrm{CC}$, а також спрогнозувати шляхом моделювання можливі наслідки реалізації різноманітних заходів. 